Original Research Paper

\title{
Pelatihan Rancang Bangun Alat Deteksi Kelelahan Berbasis Sinyal Plethysmograph untuk Meningkatkan Kualitas Kerja Dan Kesehatan di SMK 3 Pancasila Kecamatan Ambulu Kabupaten Jember
}

\author{
Osmalina Nur Rahma ${ }^{1}$, Endah Purwanti ${ }^{1 *}$, Khusnul Ain ${ }^{1}$ \\ ${ }^{1}$ Proram Studi S1 Teknik Biomedis, Departemen Fisika, Fakultas Sains dan Teknologi, Universitas Airlangga, Surabaya, \\ Indonesia
}

https://doi.org/10.29303/jpmpi.v3i2.1018

Sitasi: Rahma, O. N., Purwanti, E \& Ain, K. (2022). Pelatihan Rancang Bangun Alat Deteksi Kelelahan Berbasis Sinyal Plethysmograph untuk Meningkatkan Kualitas Kerja Dan Kesehatan di SMK 3 Pancasila Kecamatan Ambulu Kabupaten Jember. Jurnal Pengabdian Magister Pendidikan IPA, 5(1)

\author{
Article history \\ Received: 04 Oktober 2021 \\ Revised: 01 Februari 2022 \\ Accepted: 07 Februari 2022 \\ *Corresponding Author: Endah \\ Purwanti, Teknik Biomedis, \\ Universitas Airlangga, Surabaya, \\ Indonesia. \\ Email: endah-p-1@fst.unair.ac.id
}

\section{Pendahuluan}

$\mathrm{K}$ ualitas kerja tanpa disadari juga dipengaruhi oleh kesehatan fisik dan mental dari pekerja. Demi meningkatkan produktivitas, terkadang Kesehatan fisik dan mental pegawai tidak diperhatikan sehingga dapat

\begin{abstract}
Kualitas kerja tanpa disadari juga dipengaruhi oleh kesehatan fisik dan mental dari pekerja. Demi meningkatkan produktivitas, terkadang Kesehatan fisik dan mental pegawai tidak diperhatikan sehingga dapat menimbulkan kelelahan yang berdampak pada kecelakaan kerja. Salah satu cara untuk mencegah kelelahan adalah dengan mengukur kelelahan yang dialami pekerja, diantaranya dengan menggunakan sensor pletyhsmograph (PPG). Sensor PPG mengukur kadar oksigen dalam darah dan dapat digunakan mengukur detak jantung seseorang. Kadar oksigen dalam darah dan detak jantung memiliki korelasi dengan kondisi mengantuk. Saat kondisi mengantuk, detak jantung mulai melambat akibat tubuh mulai dalam keadaan rileks. Dengan demikian, sensor PPG dapat digunakan untuk memonitoring kondisi mengantuk akibat kelelahan. Selain itu, bentuk sensor PPG yang lebih kecil dibandingkan elektrokariogram (EKG) membuat sensor PPG dapat dimanfaatkan menjadi alat yang portable. Hal ini bermanfaat untuk para siswa SMK sehinga mereka dapat meningkatkan kemampuan di bidang teknologi baru dan tepat guna. Peserta pelatihan sangat antusias terhadap pelaksanaan kegiatan karena mendapatkan pengetahuan baru terkait mikrokontroler dan kecerdasan buatan. Selain itu, Siswa SMK dapat memiliki tambahan kemampuan dan pengetahuan yang berguna untuk bersaing di dunia kerja, khususnya pada era revolusi industri 4.0.
\end{abstract}

Keywords: Deteksi Kelelahan; Plethysmograph; Kemitraan untuk Mencapai Tujuan; Teknologi

menimbulkan kelelahan yang berdampak pada kecelakaan kerja. Menurut data yang dipaparkan oleh International Labour Organization (ILO) sebanyak 2 juta pekerja meninggal dunia per tahunnya karena kecelakaan di tempat kerja dan $32,8 \%$ diantaranya akibat faktor kelelahan (ILO, 2010; Aulia, 2018). Menurut Departemen Ketenaga Kerjaan dan Transportasi (Depnakertrans) tahun 
2014 juga menyatakan bahwa setiap hari rata-rata terjadi 414 kecelakaan di Indonesia dan 27,8\% diantaranya disebabkan oleh kelelahan. Kecelakaan kerja terserbut menyebabkan kurang lebih 9,5\% pekerja mengalami cacat fisik (Susanti, 2019).

Kelelahan merupakan suatu kondisi yang dialami oleh seseorang sebagai mekanisme tubuh untuk mempertahankan diri. Kelelahan ditandai dengan timbulnya rasa kantuk, cemas, berkurangnya keseimbangan serta menurunnya konsentrasi. Hal ini yang menyebabkan kelelahan menjadi salah satu faktor penyebab menurunnya produktivitas rajin dalam melakukan pekerjaan (Ningsih dan Nilamsari, 2018).

Kelelahan terjadi apabila fase pemulihan pada tubuh belum terjadi secara sempurna, namun beban dari kontraksi otot masih berlangsung secara kontinyu. Hal ini menyebabkan terjadinya penumpukan asam laktat, yang merupakan hasil dari oksidasi glukosa menjadi tenaga (Aulia, 2018). Penumpukan asam laktat ini akan bisa terurai kembali bila tubuh beristirahat, namun bila tetap terus dipaksa bekerja maka tubuh dengan sendirinya akan memaksa untuk beristirahat dengan timbulnya kelelahan (Sedarmayanti, 2009). Apabila kelelahan muncul saat bekerja, akan menimbulkan hilangnya konsentrasi dan juga kantuk. Hal ini yang dapat memicu terjadinya kecelakaan kerja. Oleh karena itu kelelahan perlu dicegah sebelum menimbulkan efek yang tidak diinginkan.

Salah satu cara untuk mencegah kelelahan adalah dengan mengukur kelelahan yang dialami pekerja dalam melakukan pekerjaan, selanjutnya dapat diatur kembali beban kerja agar sesuai dengan kapasitas fisik maupun mental tenaga kerja. Selain itu, dengan mengetahui tingkat kelelahan, maka pekerja ataupun individu lain dapat mengatur sendiri kapan harus beristirahat agar tidak membahayakan kesematan dan kesehatannya. Tanda-tanda kelelahan diantaranya adalah mengantuk. Mengantuk merupakan mekanisme tubuh dalam mempertahankan kondisi tubuh agar tetap prima, namun apabila mengantuk di saat yang tidak tepat seperti saat menyetir atau bekerja dapat berakibat fatal karena dapat mengakibatkan kecelakaan. Beberapa penelitian terkait deteksi mengantuk sebagai monitoring kelelahan sudah banyak dikembangkan, diantaranya dengan menggunakan sensor pletyhsmograph (PPG). Sensor PPG mengukur kadar oksigen dalam darah dan dapat digunakan mengukur detak jantung seseorang. Kadar oksigen dalam darah dan detak jantung memiliki korelasi dengan kondisi mengantuk (Lee,2019). Saat kondisi mengantuk, detak jantung mulai melambat akibat tubuh mulai dalam keadaan rileks. Dengan demikian, sensor PPG dapat digunakan untuk memonitoring kondisi mengantuk akibat kelelahan. Selain itu, bentuk sensor PPG yang lebih kecil dibandingkan elektrokariogram (EKG) membuat sensor PPG dapat dimanfaatkan menjadi alat yang portable (portable device).

Berdasarkan uraian latar belakang tersebut akan dilakukan Pelatihan pembuatan alat deteksi kelelahan yang berdasarkan pada sensor PPG dan diharapkan bisa digunakan oleh masyarakat luas, khususnya pekerja dalam membantu untuk mengurangi risiko kelelahan saat bekerja. Pelatihan pembuatan alat deteksi kelelahan ini dapat diberikan kepada siswa SMK jurusan teknik pemesinan, teknik kendaraan ringan otomotif, dan teknik pengelasan yang memiliki kemampuan dalam merangkai rangkaian elektronik. Dengan demikian, kegiatan ini nantinya dapat membantu meningkatkan kemampuan entrepreneurship siswa SMK dalam membuat alat deteksi kelelahan berdasarkan renpon refleks berbasis audio visual.

Wirausaha di bidang alat-alat kesehatan seperti alat deteksi kelelahan ini, dalam arti memproduksi secara mandiri dan memasarkan alatalat kesehatan di dalam negeri masih sangat sedikit. Pihak pemberi pekerjaan lebih mengandalkan peralatan medis yang didatangkan dari luar negeri. Bila diamati dan dipelajari, bahwa alat-alat kesehatan dari luar negeri sebenarnya memiliki sistem elektro-mekanik yang sederhana, sehingga memiliki peluang yang besar untuk memproduksi sendiri. Menghadapi zona perdagangan bebas, beberapa kendala yang dihadapi oleh pasar alat kesehatan, di antaranya: persaingan pasar alat kesehatan yang besar, kebutuhan akan inovasi produk, Pilihan konsumen yang lebih banyak, kebutuhan peningkatan daya saing industri, kebutuhan peningkatan kualitas SDM dan tuntutan standard alat kesehatan

Berdasarkan analisis situasi tersebut, maka melalui kegiatan pengabdian masyarakat Program Kemitraan Masyarakat ini, dapat diberikan bekal keahlian kepada sekelompok masyarakat tertentu yaitu kelompok masyarakat yang memiliki bekal keilmuan tentang elektronika, dalam hal ini yang dapat diberikan pelatihan adalah siswa ekolah 
Menengah Kejuruan (SMK). Para siswa SMK diharapkan nantinya setelah lulus mampu mengembangkan produksi dan pengadaan alat kesehatan secara mandiri di Indonesia dalam menghadapi Masyarakat Ekonomi Asean (MEA). (Ain, dkk., 2021).

\section{Metode}

Kegiatan pengabdian kepada masyarakat ini bermitra dengan SMK 3 Pancasila Ambulu dan juga CV. Inbiomed Tech. Para siswa SMK diberi pelatihan dalam membuat alat deteksi kelelahan sederhana berbasis sinyal PPG dan mikrokontroler. Pelatihan dilaksanakan secara blended, yaitu luring dengan peserta terbatas di SMK 3 Pancasila Ambulu yang beralamat di Jl. Kopral Soetomo No 266, Karanganyar, Ambulu, Kabupaten Jember, Jawa Timur serta secara daring menggunakan Zoom.

Kegiatan pengabdian kepada masyarakat ini dibagi menjadi 2 sesi, yaitu sesi pemaparan materi dan workshop atau pelatihan pembuatan alat oleh dosen Prodi Teknik Biomedis, Departemen Fisika, Fakultas Sains dan Teknologi, Universitas Airlangga serta didampingi oleh mahasiswa S1 Teknik Biomedis. Materi yang dipaparkan mengenai dasar mikrokontroler serta dasar kecerdasan buatan (Artificial Intelligent) dan dasar Internet of Things sebagai tambahan wawasan untuk siswa yang dapat dikembangkan pada alat deteksi kelelahan. Sesi kegiatan pengabdian kepada masyarakat kemudian dilanjut dengan sesi pelatihan yang didampingi oleh mahasiswa S1 Teknik Biomedis. Jumlah Siswa yang ikut dalam pelatihan ini adalah 20 siswa SMK yang kemudian dibagi menjadi 10 kelompok dan masing-masing kelompok dipandu oleh 1 mahasiswa.

Pelatihan pada siswa SMK diberikan oleh mahasiswa S1 Teknik Biomedis yang telah dilatih terlebih dahulu oleh mitra industri, yakni CV. Inbiomed Tech. yang merupakan start-up dari alumni S1 Teknik Biomedis yang bergerak di bidang prototyping alat kesehatan dan bidang lainnya. Pelatihan yang diberikan berupa pembuatan alat deteksi kelelahan berbasis sinyal PPG. Alat yang dibutuhkan untuk pelaksanaan pelatihan meliputi, sensor SPO2 untuk mengukul sinyal PPG dan heart rate pada jari tangan, Arduino Nano sebagai pemroses data serta beberapa komponen elektronik pendukung seperti layer LCD dan komponen pendukung lainnya.

Pembuatan alat kesehatan deteksi kelelahan ini meliputi perancangan software pada Arduino nano yang tujuannya untuk menampilkan hasil sinyal PPG yang telah dianalisa berupa detak jantung dan kadar oksigen dalam darah. Definisi kelelahan dari hasil alat dini ditunjukkan dari nilai detak jantung pada retang tertentu yang akan menunjukkan bahwa subjek lelah/mengantuk atau tidak. Selanjutnya masing-masing modul diuji kinerjanya berdasarkan linieritas dan stabilitasnya pada siswa SMK, hingga akhirnya para siswa menjadi paham untuk mewujudkan suatu alat kesehatan deteksi kelelahan.

Pelatihan dimulai dengan meng-install seluruh modul yang diperlukan ke Arduino kemudian merangkain komponen pada bread board, seperti yang tampak pada Gambar 1. Pelatihan kemudian dilanjukan dengan pemrograman yang dilakukan melalui Arduino IDE untuk memfungsikan seluruh sensor dalam alat sesuai kebutuhan (Pasha, 2016). Secara keseluruhan skematik rangkaian deteksi kelelahan terlihat pada Gambar 2.

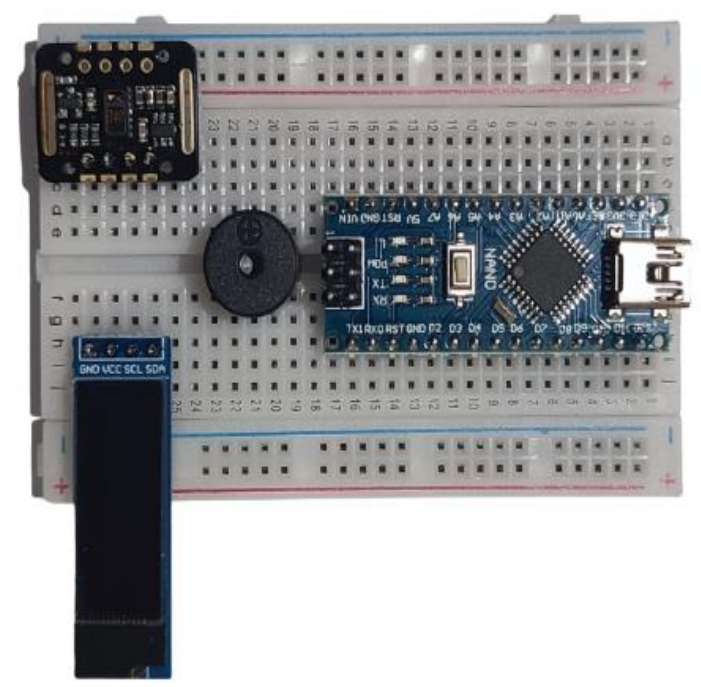

Gambar 1 Rangkaian Deteksi Kelelahan di Atas Breadboard 


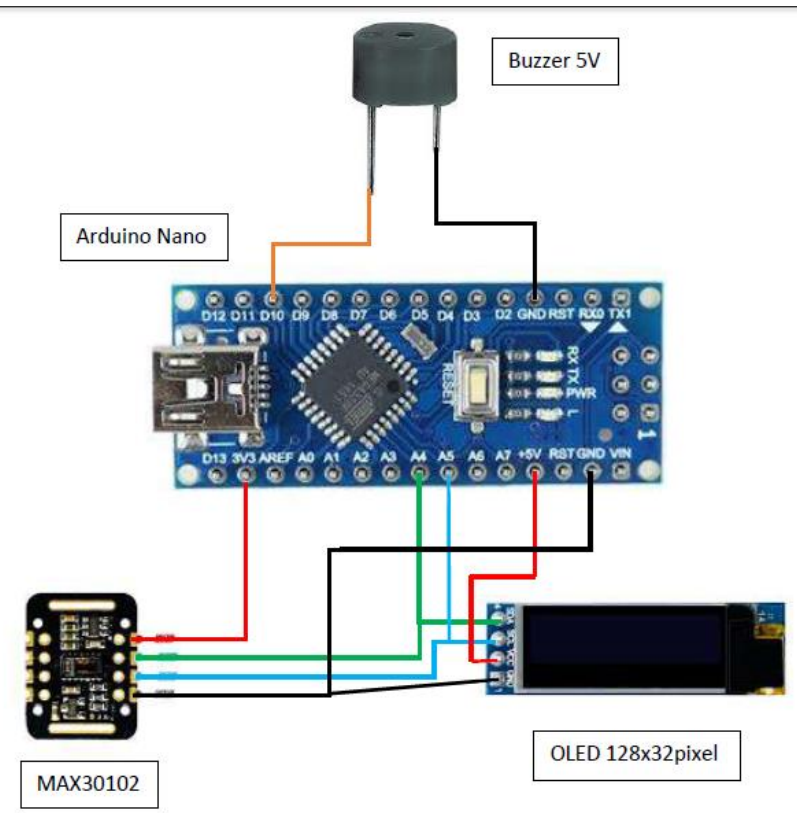

Gambar 2 Skematik Rangkaian Deteksi Kelelahan

Saat jari ditempatkan pada sensor, detak jantung dan perkiraan kadar oksigen darah ditampilkan pada layer LCD. LED merah berkedip sekali per detak jantung. Tampilan PPG diperbarui setiap 50 milidetik. Prototipe berbentuk box atau kotak dimana sensornya dirancang sedemikian mungkin sehingga prototipe dapat berukuran kecil dan portable.

Pelaksanaan kegiatan pengabdian kepada masyarakat ini kemudian dievaluasi dengan menggunakan sistem kuisioner yang akan menilai pengetahuan siswa sebelum daan sesudah pelaksanaan pengabdian masyarakat terkait materi pelatihan yang telah diberikan. Selain itu, pihak siswa dan guru SMK 3 Pancasila Ambulu juga diberi dan juga diberi kuisioner kepuasan pelaksanaan pelatihan. Pihak guru dan juga siswa juga diberikan kesempatan untuk menyampaikan pesan dan kesannya selama mengikuti pelatihan ini dan hasil dari kuisioner tersebut akan menjadi bahan evaluasi sehingga nantinya program pengabdian kepada masyarakat ini dapat berjalan dengan lebih baik ke depannya. Program ini diharapkan dapat berkelanjutan pada pihak SMK dengan adanya modul yang telah diberikan.

\section{Hasil dan Pembahasan}

Kegiatan pengabdian masyarakat yang bertemakan alat deteksi kelelahan ini dilakukan dalam 2 sesi, yaitu pemberian materi dasar dan pelatihan dasar elektronika dan mikrokontroler kepada siswa-siswa SMK 3 Pancasil. Kedua kegiatan ini dilakukan secara bersamaan pada tanggal 18 September 2021. Penyampaian materi dilakukan oleh Dr. Prihartini Widiyanti, drg., M.Kes., Limpat Salamat, S.T., Akif Rahmatillah, S.T., M.T., Endah Purwanti, S.Si., M.T., dan Franky Chandra Satria Arisgraha, S.T., M.T. dengan tujuan memberikan pemahaman dasar mengenai pentingnya vaksinasi di masa pandemi COVID-19, dasar mikrokontroller, pengenalan Artificial Intelligence dan Internet of Things.

Pelaksanaan kegiatan pengabdian masyarakat Departemen Fisika dibuka oleh Koordinator Program Studi S1 Teknik Biomedis Universitas Airlangga, Dr Riries Rulaningtyas, M.T., kemudian dilanjutkan sambutan dari Kepala Sekolah SMK 3 Pancasila, yaitu Bapak Ibnu Supriyadi, S.H., M.Si, M.Si. Pemberian materi diawali dengan penyampaian tentang apa dan mengapa vaksinasi COVID-19. Pemberian materi ini dilanjutkan oleh pemaparan alumni Limpat Salamat, S.T., terkait start up dan kiat-kiat membangun bisnis. Selanjutnya, materi pengenalan mikrokontroller dan Internet of Things diberikan oleh Akif Rahmatillah, S.T., M.T. dan Franky Chandra Satria Arisgraha, S.T., M.T. Pengenalan dasar mikrokontroler ini bertujuan agar para siswa mengetahui aplikasi elektronika yang lebih lanjut dan sudah banyak aplikasinya di kehidupan seharihari, salah satunya sebagai sistem deteksi kelelahan ini. Sebagai penutup, materi terkait Artificial Intelligence diberikan oleh Endah Purwanti, S.T, M.T. sebagai pengantar untuk workshop siswa.

Pelatihan tidak hanya dengen sistem ceramah, tetapi juga melakukan praktik secara langsung dengan komponen-komponen elektronika yang sudah ada. Para siswa diberikan pre tes dan post test untuk sebelum dan setelah materi diberikan. Berdasarkan hasil pre test dan post test, diperoleh bahkan nilai siswa meningkat 7,24\% setelah materi diberikan. Dengan demikian dapat terlihat perbedaan dari sebelum dan setelah pemberian materi.

Setelah mendapatkan materi pendukung, para siswa juga mendapatkan workshop atau pelatihan langsung mengenai mikrokontroler yang didampingi oleh mahasiswa di masing-masing breakout room Zoom. Pelatihan meliputi merangkai komponen elektronika serta membuat program yang ditanamkan ke dalam mikrokontroler. Latihan 
yang diberikan kepada para siswa meliputi bagimana merangkai komponen secara simulasi menggunakan Tinkercad maupun merangkai langsung sistem pendeteksi kelelahan berbasis sinyal PPG. Sistem ini menggunakan sensor SPO2 yang dapat mendeteksi kelelahan berbasis kadar oksigen dalam darah serta heart rate. hasilnya ditampilkan ke LCD dan buzzer akan menyala bila sensor mendeteksi nilai saturasi oksigen dan heart rate kurang dari normal. Hal ini menandakan bahwa subjek mengalami kelelahan dan perlu beristirahat.

Para siswa sangat antusias dengan adanya pelatihan elektronika dasar dan mikrokontroler ini, karena tidak hanya pemberian materi, tetapi juga melakukan praktik yang sangat berguna nantinya. Sebagian besar peserta juga ikut andil aktif dalam proses pelatihan, mulai dari memberikan berbagai macam pertanyaan, antusias dalam melakukan percobaan dan lain-lain. Mereka yang pada umumnya jarang mendapatkan praktikum yang berhubungan dengan elektronika menjadi bersemangat, apalagi ketika praktek langsung menggunakan mikrokontroler yang belum pernah mereka temui.

Kegiatan pengabdian masyarakat ini juga melakukan evaluasi terhadap proses yang telah dilakukan dengan memberikan kuisioner kepada pasar peserta, dalam hal ini para siswa dan juga guru pendamping. Hasil dari kuisioner ini akan menjadi tolak ukur keberhasilan dari acara ini. Kuisioner ini berisi tentang kualitas materi dan narasumber, manajemen dan organisasi acara, fasilitas selama kegiatan pengabdian kepada masyarakat dan dukungan unit kerja terhadap pelaksanaan kegiatan. Sebagian besar peserta mengungkapkan bahwa acara pengabdian kepada masyarakat ini sangat bermanfaat dan diharapkan mampu berkelanjutan. Seperti yang telah disampaikan oleh Kepala SMK 3 Pancasila, Ibnu Supriyadi, "Saya mengucapkan banyak terima kasih atas kerjasama Tim Pengabdian Masyarakat Departemen Fisika dengan SMK 3 Pancasila. Semoga dapat banyak memberikan manfaat bagi kita semua dan siswa kami juga termotivasi untuk melanjutkan studinya dan juga meningkatkan keahliannya". Setidaknya ini adalah awal yang sangat baik. Tentu saja saya atas nama lembaga sangat berharap tindak lanjut dan kerjasama dalam bentuk lainnya. Hal-hal inovatif seperti inilah yang sangat diharapkan sekolah demi skill peserta didik yang lebih baik.

Pengenalan dasar mikrokontroler ini bertujuan agar para siswa mengetahui aplikasi elektronika yang lebih lanjut dan sudah banyak aplikasinya di kehidupan sehari-hari, salah satunya sebagai sistem deteksi kelelahan ini. Pelatihan meliputi pengertian mikrokontroler, jenis-jenisnya, bagian-bagiannya dan cara membuat program yang diisikan ke mikrokontroler tersebut. Pelatihan tidak hanya dengen sistem ceramah, tetapi juga melakukan praktik secara langsung dengan komponen-komponen mikronkontroler yang sudah ada. Pelaksanaan pelatihan dapat dilihat pada Gambar 3 dan 4.

Kegiatan pengabdian masyarakat ini juga melakukan evaluasi terhadap proses yang telah dilakukan dengan memberikan kuisioner kepada para peserta, dalam hal ini para siswa dan juga guru pendamping. Hasil dari kuisioner ini akan menjadi tolak ukur keberhasilan dari acara ini. Kuisioner ini berisi tentang kualitas materi dan narasumber, manajemen dan organisasi acara, fasilitas selama kegiatan pengabdian kepada masyarakat dan dukungan unit kerja terhadap pelaksanaan kegiatan.

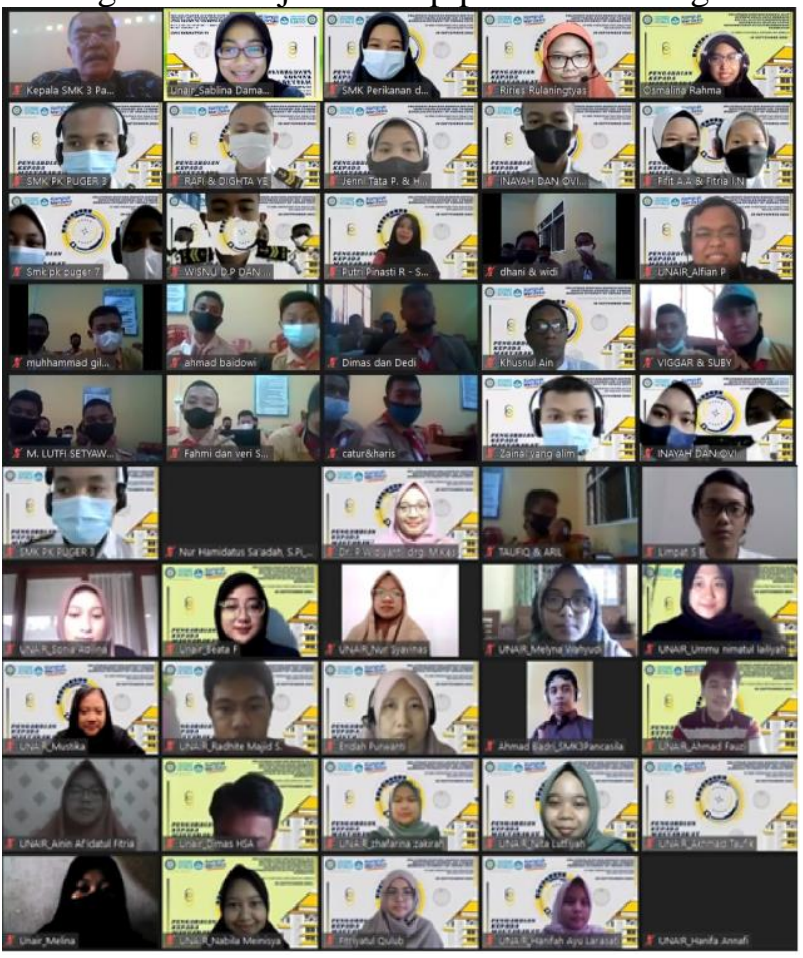

Gambar 3. Pelaksanaan Pelatihan secara daring 


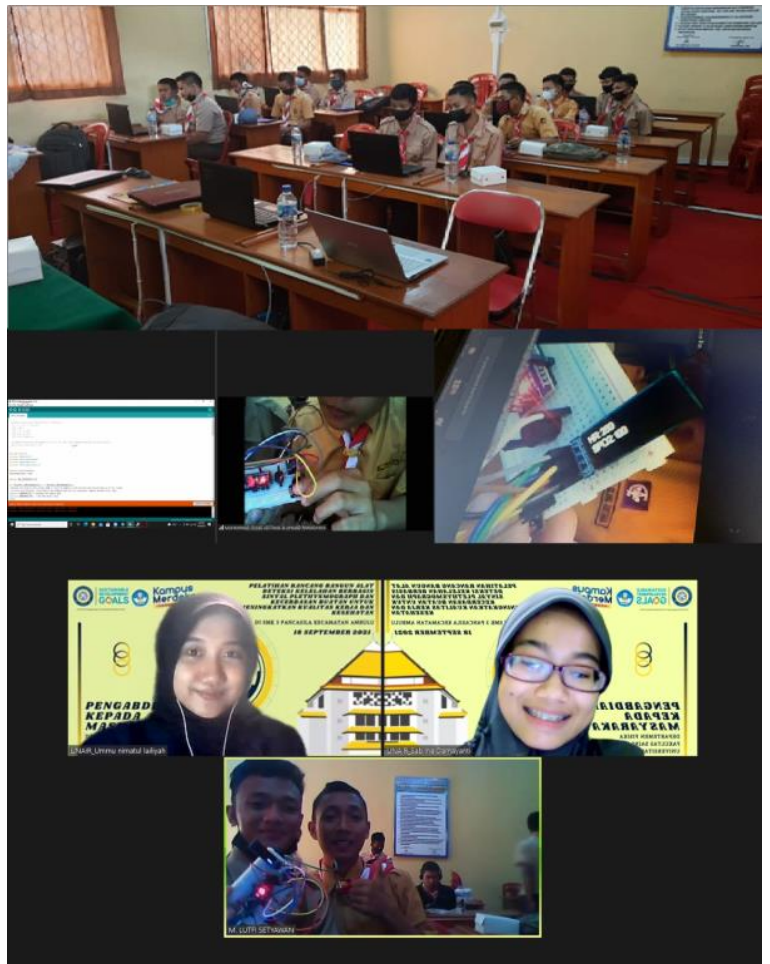

Gambar 4. Pelaksanaan Pelatihan secara Luring dan dipandu secara Daring

Sebagian besar peserta mengungkapkan bahwa acara pengabdian kepada masyarakat ini sangat bermanfaat dan diharapkan mampu berkelanjutan. Seperti yang telah disampaikan oleh Kepala SMK Perikanan dan Kelautan Puger, Bapak Drs. H. Kuntjoro Basuki, M.Si., "Saya mengucapkan banyak terima kasih atas kerjasama Tim Pengabdian Masyarakat Departemen Fisika dengan SMK Perikanan dan Kelautan. Semoga dapat banyak memberikan manfaat bagi kita semua dan siswa kami juga termotivasi untuk meningkatkan keahliannya. Semoga kegiatan seperti ini tetap bisa dilaksanakan ke depannya. Setidaknya ini adalah awal yang sangat baik. Tentu saja saya atas nama lembaga sangat berharap tindak lanjut dan kerjasama dalam bentuk lainnya. Hal-hal inovatif seperti inilah yang sangat diharapkan sekolah demi skill peserta didik yang lebih baik."

Hasil rekapitulasi nilai dari kuisioner yang telah diisi oleh peserta pelatihan dapat dilihat pada Tabel 1. Keterangan yang diberikan pada Tabel 1 merupakan tingkatan jawaban yang diberikan berdasarkan tiap pertanyaan pada kuisioner.

Tabel 1 Rekapitulasi Nilai Kuisioner Peserta Pelatihan

\begin{tabular}{lll}
\hline No. & URAIAN & SKOR \\
\hline
\end{tabular}

\begin{tabular}{|c|c|c|}
\hline No. & URAIAN & SKOR \\
\hline & I. Kualitas Materi dan Nara Sumber & \\
\hline 1 & Kemutakhiran Materi yang disajikan & 4.63 \\
\hline 2 & Kemanfaatan Materi yang diberikan & 4.69 \\
\hline 3 & Kualitas Penyampaian Materi & 4.71 \\
\hline 4 & $\begin{array}{l}\text { Kualitas Pendampingan Praktikum/Demo } \\
\text { II. Manajemen dan Organisasi }\end{array}$ & 4.66 \\
\hline 5 & $\begin{array}{l}\text { Pemilihan Waktu (hari, tanggal, dan jam) } \\
\text { kegiatan yang tepat }\end{array}$ & 4.40 \\
\hline 6 & $\begin{array}{l}\text { Publikasi/Undangan Kegiatan Yang } \\
\text { Memadai }\end{array}$ & 4.43 \\
\hline 7 & $\begin{array}{l}\text { Pengaturan Waktu dan Acara Selama } \\
\text { Kegiatan }\end{array}$ & 4.44 \\
\hline 8 & $\begin{array}{l}\text { Kemudahan Memperoleh Informasi Dari } \\
\text { Panitia }\end{array}$ & 4.66 \\
\hline 9 & $\begin{array}{l}\text { Kualitas Layanan Panitia Selama Kegiatan } \\
\text { Pengmas }\end{array}$ & 4.44 \\
\hline 10 & $\begin{array}{l}\text { III. Fasilitas Selama Kegiatan Pengmas } \\
\text { Ketersediaan Fasilitas Pendukung Selama } \\
\text { Kegiatan Berlangsung }\end{array}$ & 4.66 \\
\hline 11 & $\begin{array}{l}\text { Ketersediaan Fasilitas Media Pembelajaran } \\
\text { (LCD, Komputer, Peraga, Peralatan } \\
\text { Praktikum, dsb.) }\end{array}$ & 4.83 \\
\hline 12 & $\begin{array}{l}\text { Kenyamanan Ruang Kelas/Lab. Yang } \\
\text { Digunakan }\end{array}$ & 4.49 \\
\hline 13 & Ketersediaan Kit Pelatihan & 4.49 \\
\hline 14 & $\begin{array}{l}\text { Kualitas Konsumsi Yang Disediakan } \\
\text { IV. Dukungan Unit KerjaTerhadap } \\
\text { Pelaksanaan Kegiatan Pengmas }\end{array}$ & 4.80 \\
\hline 15 & $\begin{array}{l}\text { Sekolah tempat Saudara mengajar/belajar } \\
\text { mendukung kegiatan ini }\end{array}$ & 4.71 \\
\hline 16 & $\begin{array}{l}\text { Dinas Pendidikan di wilayah Saudara } \\
\text { mendukung kegiatan ini }\end{array}$ & 4.77 \\
\hline
\end{tabular}

Keterangan Tabel:

$1=$ Tidak bermanfaat

$2=$ kurang bermanfaat

$4=$ cukup bermanfaat

$5=$ sangat bermanfaat

Berdasarkan Tabel 1, terlihat bahwa sebagian besar peserta pelatihan menjawab dengan poin 4 atau lebih yang berarti memuaskan ketika diberi pertanyaan mengenai kualitas materi dan narasumber, managemen dan organisasi acara, fasilitas selama kegiatan dan dukungan unit kerja terhadap pelaksanaan kegiatan pengabdian masyarakat. Hal ini menunjukkan bahwa material yang disampaikan mampu membuat para siswa tertarik, mudah dipahami, dan meningkatkan wawasan para peserta pelatihan. Selain itu, dari hasil tersebut merepresentasikan bahwa pembawa materi mampu menyampaikan materi dengan baik dan benar sesuai dengan target yang telah ditentukan di awal. Adanya praktik yang diberikan kepada para peserta mampu meningkatkan 
pemahaman peserta pelatihan terhadap materi yang telah diberikan. Suasana pelatihan yang kondusif didukung dengan aktifnya peserta dalam tanya jawab mampu menghidupkan suasana kelas. Hal ini ditunjukkan dengan nilai hasil kuisioner yang berkaitan dengan fasilitas selama kegiatan pengabdian kepada masyarakat dengan hasil memuaskan (nilai lebih dari 4). Sebagain besar peserta memberikan nilai yang sedang dalam hal pemilihan waktu kegiatan dan memperoleh informasi dari panitia (nilai di bawah 4). Hal ini menjadi bahan evaluasi untuk kegiatan pengabdian kepada masyarakat tahun selanjutnya untuk lebih memperhitungkan waktu pelaksanaan kegiatan. Jadwal pelatihan sebenarnya sudah sesuai dengan jadwal yang direncanakan, tetapi terkait waktu pelatihan yang bersamaan dengan jam pelajaran aktif sehingga dirasa kurang efektif. Masukan yang didapatkan dari peserta pelatihan merupakan saransaran yang membangun untuk perbaikan pada acara selanjutnya.

Selain itu, pelaksanaan pengabdian kepada masyarakat kali ini yang pertama dilakukan secara daring dirasa cukup berhasil dimana peserta masih dapat berperan aktif selama kegiatan. Namun, memang pelatihan secara tatap muka langsung masih menjadi harapan semua peserta. Secara umum, hasil dari pelaksanaan kegiatan pengabdian kepada masyarakat ini berjalan dengan lancer, sangat memuaskan dan diharapkan dapat bersifat berkelanjutan.

\section{Kesimpulan}

Kegiatan pengabdian masyarakat yang dilaksanakan di SMK 3 Pancasila Ambulu pada tanggal 18 September 2021 berjalan dengan baik, meskipun dalam keadaan pandemic seperti saat ini. Pelaksanan kegiatan ini berjalan dengan hybrid, yaitu gabungan antara kegiatan daring dan luring. Pemberian materi dan pemanduan pelatihan dilakukan secara daring dan siswa SMK sebagai peserta pelatihan datang ke sekolah untuk melakukan pelatihan merangkai sistem monitoring secara langsung. Dari pelaksanaan kegiatan ini dapat disimpulkan bahwa peserta pelatihan sangat antusias terhadap pelaksanaan kegiatan karena mendapatkan pengetahuan baru terkait mikrokontroler dan kecerdasan buatan. Siswa SMK dapat didorong untuk aktif mendukung kemandirian bangsa terhadap alat kesehatan dengan belajar mempelajari instrumentasi medis sederhana, yang diawali dengan memahai dasar mikrokontroller dan dasar kecerdasan buatan. Semua pihak berharap kegiatan seperti ini dapat berlangsung secara kontinu dan bisa dikembangkan lagi di kegiatan mendatang.

\section{Saran}

Saran untuk kegiatan pengabdian kepada masyarakat di tahun selanjutnya adalah diharapkan program pengabdian kepada masyarakt dapat berkelanjutan hingga pengaplikasian, peningkatan jumlah peserta pelatihan dengan topik yang lebih aplikatif serta pelatihan bisa dilaksanakan secara luring dengan durasi praktik lebih panjang.

\section{Ucapan Terima Kasih}

Penulis mengucapkan terima kasih kepada Fakultas Sains dan Teknologi Universitas Airlangga yang telah memberi dukungan finansial terhadap pelaksanaan kegiatan pengabdian masyarakat ini dengan Dana Rencana Kegiatan Anggaran Tahunan (RKAT) 2021 dengan Nomor 388/UN3/2021 Tanggal 7 Mei 2021.

\section{Daftar Pustaka}

Ain, K., Rulaningtyas, R., \& Putra, A. P. (2021). Pelatihan Rancang Bangun Alat Deteksi Kelelahan Berbasis Audiovisual untuk Meningkatkan Kualitas Kerja Dan Kesehatan di SMK 3 Pancasila Kecamatan Ambulu Kabupaten Jember Provinsi Jawa Timur. Jurnal Pengabdian Magister Pendidikan IPA, 4.

Aulia, Aladin, Mariaman T. (2018). Hubungan kelelahan kerja dengan kejadian Kecelakaan kerja pada pekerja. Jurnal Kesmas \& Gizi (JKG) Vol. 1 No.1 Edisi Mei-Oktober 2018.

ILO. (2010). Kesehatan dan Keselamatan Kerja di Tempat Kerja. Jakarta: ILO

Lee, Hyeonjeong. Lee, Jaewon, Shin, Miyoung. (2019). Electronics. MDPI: Vol 8 No. 192. doi:10.3390/electronics 8020192

Ningsih, S. N. P. dan Nilamsari, N., 2018, Faktor yang berhubungan dengan Kelelahan pada Pekerja Dipo Lokomotif PT. Kereta Api Indonesia (Persero). Journal of Industrial 
Hygiene and Occupational, Health. Vol. 3, No. 1, pp. 69-82.

Pasha, S., 2016. Thingspeak Based Sensing and Monitoring System for IoT with Matlab Analysis. International Journal of New Technology and Research (IJNTR) Vol. 2, Issue 6, pp. 19-23

Sedarmayanti. 2009. Sumber Daya Manusia dan Produktivitas. Bandung: CV Mandar Maju. (OHSAS 18001). Seri Manajemen K3. Jakarta. PT Dian Rakyat.

Susanti, S., AP Amelia, A Rizki., (2019). Faktor yang Berhubungan dengan Kelelahan Kerja pada Pekerja PT Maruki International Indonesia Makassar Tahun 2018. Sinergitas Multidisiplin Ilmu Pengetahuan dan Teknologi, vol. 2, 2019, ISSN: 2622-052 